\title{
O DESABROCHAR DA ESTÉTICA MODERNISTA EM MÁRIO DE ANDRADE
}

\author{
THE DEVELOPMENT OF MODERNIST AESTHETICS IN \\ MARIO DE ANDRADE \\ EL DESARROLLO DE LA ESTÉTICA MODERNISTA EN \\ MÁRIO DE ANDRADE
}

\author{
Tânia Cristina Amaral \\ Mestre pelo Programa de Pós-Graduação em Geografia \\ Universidade de São Paulo \\ taniamaral@usp.br
}

\begin{abstract}
Resumo: Esse artigo é parte do tema de pesquisa da dissertação de mestrado. A paisagem urbana da cidade de São Paulo: uma poética da garoa sob o olhar de Mário de Andrade. O desabrochar da estética Modernista em Mário de Andrade, sublinha um período marcado pelo movimento de renovação estética literária e artística no Brasil, que instaura e coroa a arte e a literatura, com profundas modificaçóes atreladas aos organismos sociais e políticos no país. Mário de Andrade, o poeta modernista, arlequinal e lírico, engajado nas vanguardas europeias através da literatura e, junto a outros importantes nomes de veios artísticos, inaugura a revolução na arte do Brasil com a Semana de Arte Moderna em fevereiro de 1922, na cidade de Sáo Paulo. Esta pesquisa debruça-se nos estudos da representação da cidade de São Paulo no viés poético e geográfico, quando correlaciona a vida e morte do poeta ao processo de urbanização da cidade de São Paulo. Esse contexto é revelado através dos poemas que perpetuam o amor visceral entre a cidade e Mário, o qual a elege como tema principal. As cortinas se abrem e, segundo o olhar imagético do poeta, a leitura sobre o arranjo espacial da cidade é concluída.
\end{abstract}

Palavras chaves: Mário de Andrade. São Paulo. Modernismo. Cidade. Poesia.

\begin{abstract}
This article is part of the research theme of the master's thesis. The urban landscape of the city of São Paulo: a poetic of the drizzle under the eyes of Mário de Andrade. The emergence of Modernist aesthetics in Mário de Andrade underlines a period marked by the movement of artistic and literary aesthetic renewal in Brazil, which establishes and crowns art and literature, with profound modifications tied to social and political organisms in the country. Mário de Andrade, the modernist, harlequin and lyricist poet, engaged in the European avant-garde through literature and, together with other important names of artistic veils, inaugurates the revolution in Brazilian art with the Modern Art Week in February 1922 in the city from Sao Paulo. This research studies the representation of the
\end{abstract}


city of São Paulo in the poetic and geographical bias, when it correlates the life and death of the poet to the process of urbanization of the city of Sáo Paulo. This context is revealed through the poems that perpetuate the visceral love between the city and Mario, which elects it as the main theme. The curtains open and, according to the poet's imagery, the reading of the space arrangement of the city is completed.

Keywords: Mário de Andrade. São Paulo. Modernism. City. Poetry.

Resumen: Este artículo es parte del tema de investigación de la disertación de maestria. El paisaje urbano de la ciudad de São Paulo: una poética de la garona bajo la mirada de Mário de Andrade. El desabrochar de la estética Modernista en Mário de Andrade, subraya un período marcado por el movimiento de renovación estética literaria y artística en Brasil, que instaura y corona el arte y la literatura, con profundas modificaciones atadas a los organismos sociales y políticos en el país. Mário de Andrade, el poeta modernista, arlequinal y lírico, comprometido en las vanguardias europeas a través de la literatura $y$, junto a otros importantes nombres de velos artísticos, inaugura la revolución en el arte de Brasil con la Semana de Arte Moderno en febrero de 1922, en la ciudad De Sao Paulo. Esta investigación se centra en los estudios de la representación de la ciudad de São Paulo en el sesgo poético y geográfico, cuando correlaciona la vida y muerte del poeta al proceso de urbanización de la ciudad de São Paulo. Este contexto es revelado a través de los poemas que perpetúan el amor visceral entre la ciudad y Mário, el cual la elige como tema principal. Las cortinas se abren y, según la mirada imaginaria del poeta, la lectura sobre el arreglo espacial de la ciudad es concluida.

Palabras claves: Mário de Andrade. São Paulo. Modernismo. Ciudad. Poesia.

\section{INTRODUÇÃO}

A representação da cidade de São Paulo na poesia de Mário de Andrade consagra o Modernismo na semana de 22 após a leitura do poema Inspiração de Pauliceia desvairada. Com fragmentos de uma sociedade marginalia inserida em uma pressuposta modernidade no início do século XX. Período marcado por profundas transformaçóes na história como a I Guerra Mundial e pelos movimentos das vanguardas europeias que marcaram a renovação estética literária e artística também no Brasil. Os anos vinte se caracterizaram por uma predominância desses manifestos. No campo artístico e literário como o futurismo, cubismo, dadaísmo, expressionismo e surrealismo, que provocaram uma verdadeira revolução na arte em todo o mundo.

Nos anos vinte no Brasil, ecoou o desabrochar da estética Modernista a partir da Semana de 22. As grandes transformaçóes urbanas da cidade de Sáo Paulo no período, que corresponde a fase de vanguarda, o poeta coloca a máscara do trovador arlequinal (LAFETÁ, 1986, p.15). Preocupado em expressar seus sentimentos diante de uma cidade cosmopolita, capitalista e estruturada nas desigualdades sociais. Mário de Andrade escreve Pauliceia desvairada e Losango cáqui. 
Algum tempo depois, a Coluna Prestes marcha para o interior e identifica um Brasil cheio de diversidades e o poeta troca de máscara ao conhecer melhor o Brasil e escreve Clã do jabuti. No final da década na solitude de suas inquietaçóes e ao virar mais uma página da história, Mário de Andrade escreve Remate de males (LAFETÁ, 1986, p.14). Essa é a primeira fase do modernista, que vai interessar ao trabalho. Além da representação da cidade de Sáo Paulo no primeiro momento modernista do poeta e a sua "figuração da intimidade", que são amplamente criticados por vários críticos literários. É na cadência desse ritmo que o poeta faz suas experimentaçóes literárias.

$\mathrm{Na}$ primeira parte o artigo trata a celebraçáo do Movimento Modernista no Brasil, suas repercussóes e avaliaçóes pelos críticos. Na segunda, a representação da cidade de São Paulo, na obra Pauliceia desvairada e a estética literária modernista diante das máscaras de Mário.

\section{A SEMANA DE ARTE MODERNA NA CIDADE DE SÁO PAULO}

É na essência da arte que está a Arte. É no sentimento vago do Infinito, que está a soberana emoção artística derivado do som, da forma, da cor. Para o artista a natureza é uma "fuga" perene no Tempo imaginário. [...] Transmitir por ela as vagas emoções absolutas vindas dos sentidos e realizar nessa emoção estética a unidade com o Todo é a suprema alegria do espírito. [...] O que hoje fixamos não é a renascença de uma arte que não existe. É o próprio comovente nascimento da arte no Brasil [...]. A vida será, enfim, vivida na sua profunda realidade estética. O próprio Amor é uma função da arte, porque realiza a unidade integral no Todo infinito pela magia das formas do ser amado. [...] (SEVCENKO, 2014, p. 269).

A abertura e pronunciamento oficial do espetáculo, no Teatro Municipal de São Paulo em 13 de fevereiro de 1922 é do próprio escritor Graça Aranha, sua fala sensível e ao mesmo tempo contundente surpreendia a plateia, que mesmo antes da abertura se acotovelavam no estacionamento e aos arredores, com seus ingressos para a celebraçáo do espetáculo modernista.

A sugestão para o título Semana de Arte Moderna, foi de Graça Aranha que pretendia abrir na capital francesa em março de 1922 um congresso internacional dedicado ao L'Esprit Nouveau, projeto esse frustrado. Mas cuja essência é oportunamente incorporada na Semana de Arte Moderna no Brasil, no qual se apresenta o novo de diversas vanguardas europeia, seja o cubismo, orfismo, expressionismo, purismo, dadaísmo, enfim o modernismo irrigado na literatura, na música e na pintura da capital paulista e no Rio de Janeiro. (ESCOREL, 2011, p. 59).

$\mathrm{Na}$ segunda noite de apresentação no majestoso Teatro Municipal de São Paulo, Luis Aranha quase dez anos mais novo que Mário de Andrade e imerso tanto quanto na literatura francesa como Nouvelle Revue Français e L'Esprit Nouveau impressionava a seleta plateia com seus versos proeminentes lidos e ecoados no amplo saláo do teatro. A garoa presente, ressoava tranquila no verso. (SEVCENKO, 2014, p. 270). 
À noite

Asfalto branco da rua

Meu amigo catedral perto de minha cabana

Garoa

Salto de luz sobre os trilhos da treva

$\mathrm{O}$ vento varre meu pensamento

Uma aranha de um metro desce do ar

E o meu guarda-chuva sob o lampião aceso.

A noite de 15 de fevereiro reviveu, no Teatro Municipal, velha prática brasileira: o público manifestava-se ruidosamente contra o espetáculo, e com vaias, assovios, gracejos, interrompia a todo instante os poetas que tentavam declamar seus versos, e os prosadores que procuravam ler trechos de romances.

Mesmo assim, o grupo "futurista" levou o programa até o final. No intervalo, no saguâo do teatro (onde estava armada a exposiçấo de pinturas e esculturas), um rapaz alto, de queixo proeminente, lábios grossos, testa larga que já mostrava sinais de calvície, voz forte e gestos amplos, reunia em torno de si um punhado de espectadores e tentava explicar-lhes as tendências artísticas contemporâneas. Nesse instante, sem que talvez tivesse plena consciência disso, aquele rapaz iniciava um destino: o de esclarecer, durante anos a fio, através de seus escritos, o sentido e os caminhos atuais das várias artes. Seu nome, o leitor já sabe: Mário de Andrade, um dos principais organizadores daquele festival tumultuado que passaria à história da literatura brasileira como acontecimento da maior importância. (LAFETÁ, 2004, p. 214).

Dessa forma, apresenta-se Mário de Andrade, o modernista e poeta que elege sua obra Paulicéia desvairada como uma das protagonistas da Semana de Arte Moderna na cidade de São Paulo de 1922. Com a leitura do seu poema Inspiração, São Paulo! comoção de minha vida... Em meio aos protestos e as múltiplas vaias que se estendiam e ecoavam pelo interior do Teatro Municipal de São Paulo, o poeta "futurista" consagra-se no modernista. "Mas como tive coragem pra dizer versos diante duma vaia táo bulhenta que eu não escutava no palco o que Paulo Prado me gritava da primeira fila das poltronas?..." (ANDRADE, 1974, pp. 231-232).

\section{INSPIRAÇÃO}

"Onde até na força do verão havia

Tempestades de ventos e frios de

Crudelíssimo inverno"

Fr. Luís de Sousa

São Paulo! Comoção de minha vida...

Os meus amores são flores feitas de original!...

Arlequinal!...Traje de losangos...Cinza e ouro... 
Luz e bruma...Forno e inverno morno...

Elegâncias sutis em escândalos, sem ciúmes...

Perfumes de Paris...Arys!

Bofetadas líricas no Trianon...Algodoal!...

São Paulo! Comoção de minha vida...

Galicismo a berrar nos desertos da América! (ANDRADE, 2009, p. 31)

Figura 1 - Avenida São João - década de 1.920

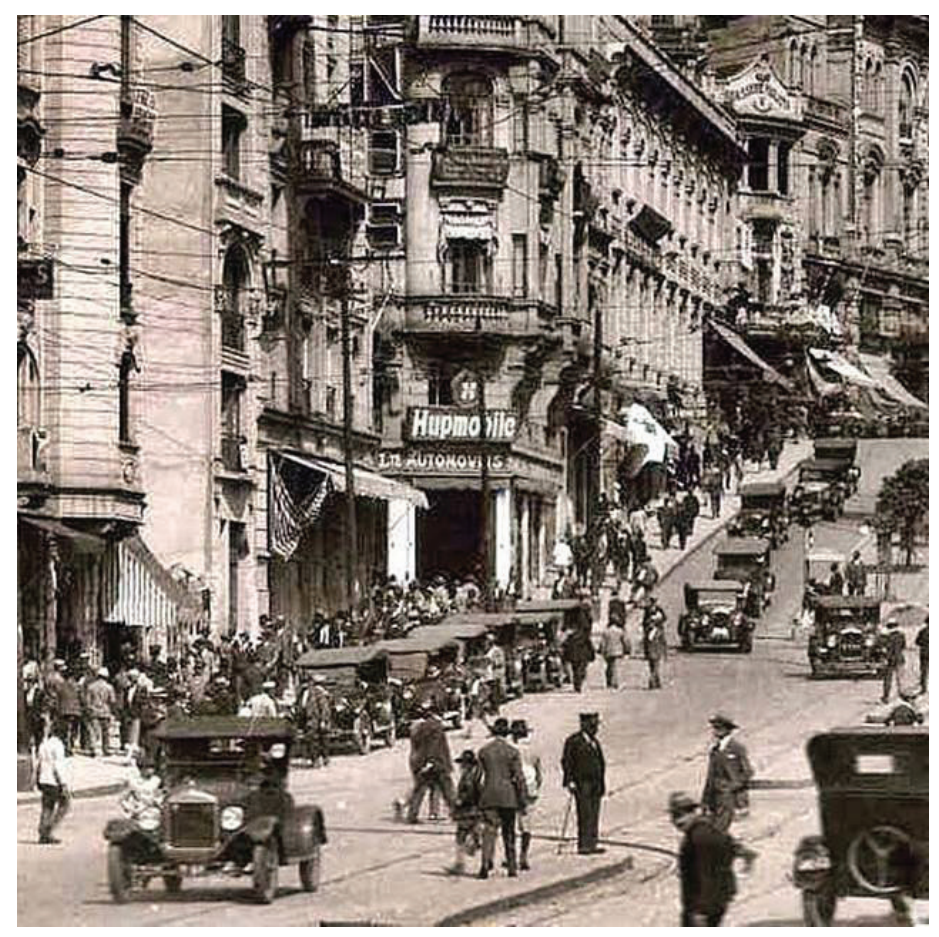

Fonte: https://de pinterest.com/pin/ acesso 15 jan. 2017

Mário e mais o grupo de escritores, músicos, poetas e artistas inauguraram L'Esprit Nouveau brasileiro, uma arte nova no país e torna São Paulo a precursora do modernismo que modifica a consciência nacional, como na fala andradiana e estabelece o sentimento da modernidade no Brasil

A Semana marca uma data, isso é inegável. Mas o certo é que a pré-consciência primeiro, e em seguida a convicção de uma arte nova, de um espírito novo, desde pelo menos seis anos viera se definindo no sentimento de um grupinho de intelectuais paulistas. De primeiro foi um fenômeno estritamente sentimental, uma intuiçấo divinatória, um... estado de poesia. Com efeito: educados na plástica "histórica", sabendo quando muito da existência dos impressionistas principais, ignorando Cézaune; o que nos levou a aderir incondicionalmente à exposição de Anita Malfatti, que em plena guerra vinha nos mostrar quadros expressionistas 
e cubistas. Parece absurdo, mas aqueles quadros foram a revelação. E ilhados na enchente de escândalo que tomara a cidade, nós, três ou quatro, delirávamos de êxtase diante de quadros que se chamavam o "Homem Amarelo", a Estudanta Russa", a Mulher de Cabelos Verdes". E a esse mesmo "Homem amarelo" e de formas tão inéditas entáo, eu dedicava um soneto de forma parnasianíssima... Éramos assim. (ANDRADE, 1974, p. 232).

A pintura de Anita Malfatti o "Homem Amarelo" mostrada a seguir, já havia sido exposta anteriormente, era sua segunda exposição em Sáo Paulo em 1917. É nessa exposição que Mário de Andrade a conhece e suas pinturas expressionistas muito o influenciará nos poemas. É a partir dessa exposição que Monteiro Lobato a crítica escreve um polêmico artigo no Jornal O Estado de São Paulo em 20 de dezembro de 1917, com o título: Paranoia ou Mistificação. Sua crítica exacerbada era principalmente pela orientaçáo estética que a artista seguia. A arte e L'Esprit Nouveau, constrangia os mais conservadores como Lobato, defensor da literatura academista e passadista.

Antes mesmo do pronunciamento da Semana de Arte Moderna, a literatura e a arte brasileira encontrava-se em estado de letargia, passadista, e carente de um "espírito novo" havia um esgotamento do Parnasianismo e do Simbolismo.

Figura 2 - O homem amarelo. 1915-16. óleo s/ tela (61×51) - Anita Malflatti

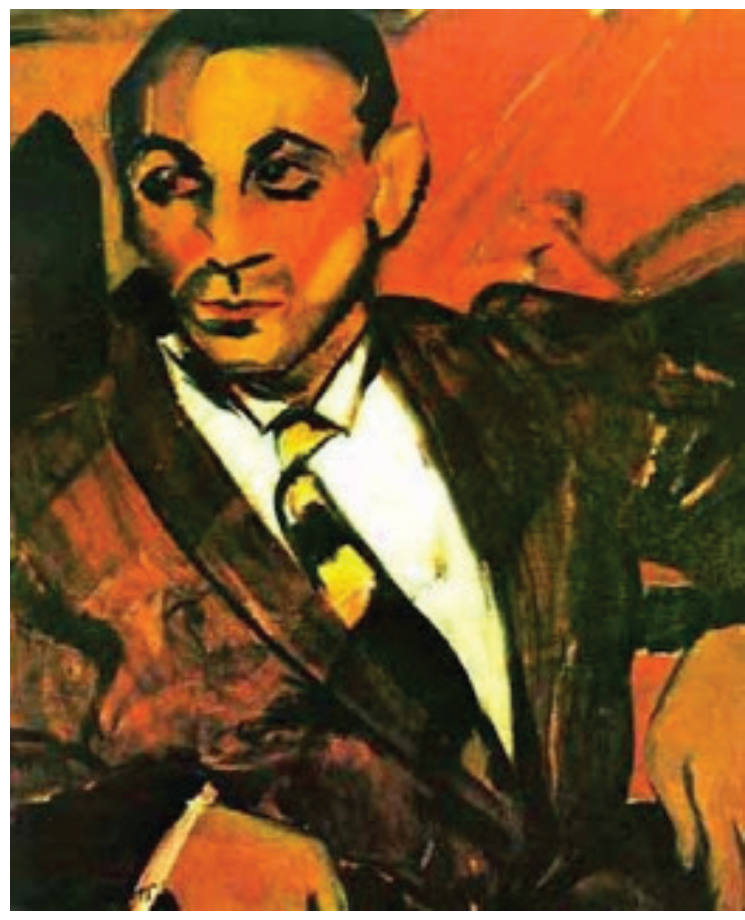

Col. Mário de Andrade, Instituto de Estudos Brasileiros da USP, SP. https://obrasanitamalfatti.wordpress.com/ acesso 10 Jan 2017.

Além dos salóes de representação artística, na música, nos encontros nos cafés e saraus os prenúncios da Semana de Arte Moderna ocorrem também atrelados a veiculação impressa dos principais jornais e revistas da cidade de Sáo Paulo, através dos escritos dos 
futuros modernistas como Oswald de Andrade, Mário de Andrade, Menotti del Picchia, entre outros.

\begin{abstract}
Nos anos 1920 e 1921, o Brasil testemunha, no panorama das artes, o despontar do movimento modernista em São Paulo, antecedendo a Semana de Arte Moderna em 1922. Oswaldo de Andrade e Menotti del Picchia, principais propagandistas do modernismo, encarrega-se, a partir de 1920, da renovaçáo estética em artigos e crônicas no Jornal do Comércio e no Correio Paulistano. Mário de Andrade escreve em Papel e Tinta, primeira reunião dos modernistas paulistanos, na Revista do Brasil, em São Paulo, e na Ilustração Brasileira, no Rio de Janeiro. (ESCOREL, 2011, p.53).
\end{abstract}

A Semana de Arte Moderna é organizada pela burguesia rural paulista. O nome mais importante destaca-se Paulo Prado, considerado o mecenas do modernismo de família oligarca paulista, rico fazendeiro do café e bastante comprometido com a renovação estética na literatura e na arte no Brasil, que mais tarde escreve um relevante e polêmico livro Retrato do Brasil em 1926 e 1928. Assumi a liderança juntamente com sua esposa francesa Marinette, do grupo dos jovens modernistas que se apresentariam no evento em nome da arte moderna. A ideia surge quando os jovens intelectuais se encontram em um dos seróes no saláo da residência de Paulo Prado em fins de 1921. (SEVCENKO, 2014, p. 268). Mário de Andrade escreve sobre o Movimento Modernista em Aspectos da literatura brasileira

O nosso sentido era especificamente destruidor. A aristocracia tradicional nos deu mão forte, pondo em evidência mais essa geminação de destino - também ela já então autofagicamente destruidora, por não ser mais uma significação legitimável.

Quanto aos aristôs do dinheiro, esses nos odiavam no princípio e sempre nos olharam com desconfiança. Nenhum saláo de ricaço tivemos, nenhum milionário estrangeiro nos acolheu. Os italianos, alemães, os israelitas se faziam de mais guardadores do bom senso nacional que Prados e Penteados e Amarais... (ANDRADE, 1974, p. 241)

Paulo Prado também se encarrega da locação do Teatro Municipal para a Semana de Arte Moderna. Os ingressos foram vendidos antecipadamente para o evento modernista contribuiriam também para o pagamento do aluguel. Além dele contaria também com seu amigo e escritor Graça Aranha recém-chegado da Europa para a liderança do grupo, e sugestão do título do evento. A publicidade do espetáculo foi promovida pelo jornal oficial o Correio Paulistano, a serviço do governo de Washington Luís.

A Semana de Arte Moderna de São Paulo realizada nos dias 13, 15 e 17 de fevereiro de 1922 é publicada pelo Jornal O Estado de S. Paulo na ediçáo do dia 3 de fevereiro de 1922 em Wilson Martins (2002, p.75).

Semana de Arte Moderna - A notícia de uma projetada "Semana de Arte Moderna”, em S. Paulo, tem despertado o mais vivo interesse nas nossas rodas intelectuais e mundanas. Os srs. Presidente do Estado e prefeito municipal prometeram aos membros da comissão organizadora o seu inteiro apoio. Os festivais da "Semana de Arte Moderna", que se realizarão no Teatro Municipal, foram denominados: o primeiro, de "Pintura e Escultura"; o segundo, da 
Literatura e da Poesia", e o terceiro, "Festival da Música". Neles tomarão parte: na literatura, o sr. Graça Aranha, que fará uma conferência sobre a "Emoçáo estética na arte moderna", e os srs. Ronald de Carvalho, Mário de Andrade, Álvaro Moreyra, Oswald de Andrade, Menotti del Picchia, Renato de Almeida, Luís Aranha, Ribeiro Couto, Moacir de Abreu, Agenor Barbosa, Rodrigues de Almeida, Afonso Schmidt, Sérgio Milliet, Guillerme de Almeida e Plínio Salgado. Na música: Guiomar Novaes, Villa-Lobos, Octavio Pinto, Paulina d'Ambrósio, Ernani Braga, Alfredo Gomes, Frutuoso e Lucília Villa-Lobos. Na escultura: Victor Brecheret, Hildegardo Leão Veloso e Haarberg. Na pintura: Anita Malfatti, Di Cavalcanti, Ferrignac, Zina Aita, Martins Ribeiro, Oswaldo Gueld (sic, por Goeldi), Regina Graz, John Graz e Castello. A procura de bilhetes para esses festivais têm sido grande.

(http://acervo.estadao.com.br/pagina/\#!/19220203-15725-nac-0003-999-3-not)

No estudo de Martins (2002, p. 82) a partir do Futurismo para o Modernismo a evolução é eminente e inicia-se com Mário de Andrade que vai deslumbrar essa fase transformadora no Brasil. O Futurismo existiu antes mesmo da Semana de Arte Moderna, antes mesmo da exposiçáo de Anita Malfatti, em 1917. Em A escrava que não é Isaura é a consagração ao "repúdio doutrinário" do Futurismo. Mesmo diante do artigo de Oswald de Andrade "O meu poeta futurista", essa palavra já era conhecida na literatura do Brasil e náo foi absorvida como parte de um movimento de vanguarda como o modernismo. Em Prefácio Interessantíssimo Mário é contundente sobre o artigo Futurista de Oswald.

Não sou futurista (de Marinetti). Disse e repito-o. Tenho pontos de contato com o futurismo. Oswald de Andrade, chamando-me de futurista, errou. A culpa é minha. Sabia da existência do artigo e deixei que saísse desejei a morte do mundo. Era vaidoso. Quis sair da obscuridade. Hoje tenho orgulho. Não me pesaria reentrar na obscuridade. Pensei que se discutiriam minhas ideias (que nem são minhas): discutiram minhas intençôes. Já agora não me calo. Tanto ridicularizariam meu silêncio como esta grita.

Andarei a vida de braços no ar, como o Indiferente de Watteau. (ANDRADE, 2009, p. 9).

Apesar da importância e repercussões até mesmo política, que teve o Movimento Modernista para o Brasil existe uma contraposiçáo por aqueles que desconsideraram o mesmo. Dizendo se tratar de um movimento aristocrático e elitizado. Promovido e patrocinado pelos intelectuais e burgueses da época. Por exemplo José Lins do Rego, em uma entrevista ao jornal Estado de Sáo Paulo em 4 de janeiro de 1958, na página de número $3^{1}$ afirma que: "para nós, de Recife, essa Semana de Arte Moderna não existiu".

Já Graciliano Ramos, em Palmeira dos Índios, em uma entrevista dada a Homero Senna sobre o Modernismo em 18 de dezembro de 1944, publicada originalmente pela

Disponível em: http://acervo.estadao.com.br/pagina/\#!/19580104-25360-nac-0039-lit-3-not/tela/fullscreen 
Revista do Globo, n. 473, responde quando lhe pergunta o interlocutor:

E que impressão lhe ficou do Modernismo?

Muito ruim. Sempre achei aquilo uma tapeação desonesta. Salvo raríssimas exceçóes, os modernistas brasileiros eram uns cabotinos. Enquanto outros procuravam estudar alguma coisa, ver, sentir, eles importavam Marinetti.

Quer dizer que não se considera modernista?

Nunca fui modernista. Enquanto os rapazes de 22 promoviam seu movimentozinho, achava-me em Palmeira dos Índios, em pleno sertão alagoano, vendendo chita no balcão. ${ }^{2}$

Wilson Martins (2002, p.61) faz uma leitura crítica sobre a Semana de Arte Moderna e sintetiza que "a Semana de Arte Moderna, justamente por seu caráter provocador e escandaloso, pôs tudo a perder; ela ergueu contra o Modernismo muito mais resistências do que ele teria normalmente despertado se realizasse, não com menos manifestos, mas com menos manifestações". Segundo o autor os passadistas não estavam tão fechados as novas ideias do espírito novo como é colocado em algumas literaturas, mas realmente quem desaprovava por completo o Modernismo eram aqueles avessos a qualquer manifestaçáo artística e literária da época. E ainda enfatiza que "foram os modernistas que fizeram a Semana de Arte Moderna e não a Semana de Arte Moderna que fez o Modernismo" (WILSON, 2002, p. 62).

Sobre a estética literária. Lafetá (1974, pp.11-12) aponta para o modernismo como um transformador da linguagem bacharelesca, artificial para uma nova entonação artística e ideológica, que modifica náo somente os veios artísticos e literários, mas também toda uma sociedade. Coloca também em que medida no estudo da história literária os limites circunscritos de uma sociedade são colocados pelos movimentos de renovação estética, que determinam as relaçóes culturais e sociais e se insere no contexto de sua própria época. E o quanto os meios tradicionais são afetados pelo poder transformador dessa nova linguagem.

Há duas faces a serem complementadas o projeto estético, ligado às modificaçóes na linguagem, e o projeto ideológico, engajada ao pensamento de sua época. O projeto estético e ideológico deve ser encarado de forma dialética como instrumentos de análise de um determinado movimento artístico. Um movimento artístico deve buscar a complementaridade em ambos projetos. O Modernismo brasileiro alcançou a renovação dos meios e ruptura da linguagem tradicional pertinente ao projeto estético e a consciência do país e a busca de uma expressão artística nacional como parte do projeto ideológico.

Lafetá (1974, p.12) coloca a relevância de considerar "o poder que tem uma ideologia de se disfarçar em formas múltiplas de linguagem; revestindo-se de meios expressivos diversos dos anteriores, pode passar por novo e crítico o que permanece velho e apenas diferente". O futurismo marinettiano, expressão do processo industrial moderno

Disponível em: http://www.tirodeletra.com.br/entrevistas/GracilianoRamos.htm. Acesso em: 20 jan. 2017. 
identifica-se com a consciência burguesa, "otimista e progressista” do século XIX. E ainda com relação ao fascismo e o nazismo, movimentos de mobilização das massas populares, demagogos, também contra-revoluções que instaura a simbólica e partidária fraude ideológica e artificial. Quanto ao caráter do movimento modernista no Brasil Lafetá complementa.

A experimentação estética é revolucionária e caracteriza fortemente os primeiros anos do movimento: propondo uma radical mudança na concepçáo da obra-dearte, vista não mais como mimese (no sentido em que o naturalismo marcou de forma exacerbada esse termo) ou representaçấo direta da natureza, mas como um objeto de qualidade diversa e de relativa autonomia, subverteu assim os princípios da expressão literária. (LAFETÁ, 1974, p.12)

A Pauliceia desvairada transforma-se na bandeira do movimento modernista, apesar da linguagem retórica, cheia de exclamaçóes, reticências e preciosismo incapaz de expressar os sentimentos do poeta, fez um enorme sucesso ao ser lida para os escritores modernistas. $\mathrm{Na}$ fase da nova estética Mário de Andrade era o professor das novas doutrinas e torna-se conhecido como o "papa do Modernismo", em Lafetá (2004, p. 220).

Não era para menos: o verso livre, sem métrica nem rima, a simultaneidade de sentimentos, e o uso constante da ambiguidade poética, todos esses recursos contrastavam de maneira radical com a poesia parnasiana, que era medida, repetitiva, linear, nítida. (LAFETÁ, 2004, p. 220)

\section{A REPRESENTAÇÃO DA CIDADE DE SÃO PAULO NA POÉTICA DE MÁRIO DE ANDRADE}

A cidade de São Paulo das primeiras décadas que antecederam os anos vinte, sob o olhar de Mário de Andrade: "A cidade moderna é o labirinto arquitetônico que o homem criou à imagem de sua alma" (LAFETÁ, 1986, p. 20). Esse debate sobre a cidade e a personalidade de Mário é amplamente discutido na literatura. Lafetá ainda coloca que Mário persegue essa identidade nos poemas da Pauliceia, ser um sujeito lírico capaz de fazer a cidade brilhar no interior do "eu", e este refletir-se na garoa ou no sol da cidade. (LAFETÁ, 1986, p. 19).

Manipulando suas antíteses, reticências e exclamaçóes, cria um traje de arlequim que veste tanto o trovador quanto a metrópole. No poema "Inspiração", a luz e a bruma, o "forno e inverno morno" - que caracterizam o espaço de São Paulo - são transportados para o traje de losangos cinza e ouro de arlequim. No poema "O Trovador", as primaveras de sarcasmo" e o frio intermitente - que caracterizam o "coração arlequinal" - correspondem à luz e à bruma, ao forno e inverno morno do poema anterior. E os versos finais de ambos exprimem a mesma tensão: São Paulo é "Galicismo a berrar nos desertos da América!", enquanto o "eu" se define como "sou um tupi tangendo um alaúde!” (LAFETÁ, 1986, p. 20) 


\section{O TROVADOR}

Sentimentos em mim do asperamente

Dos homens das primeiras eras...

As primaveras de sarcasmo

Intermitentemente no meu coração arlequinal...

Intermitentemente...

Outras vezes é um doente, um frio

$\mathrm{Na}$ minha alma doente como um longo som redondo...

Cantabona! Cantabona!

Dlorom...

Sou um tupi tangendo um alaúde! (ANDRADE, 2009, p. 32)

O clima na cidade de São Paulo é de otimismo e de euforia. Antônio Candido chamou de "consciência eufórica do país novo" (LAFETÁ, 1997, p. 89). O poeta escreve o livro de poemas Paulicéia desvairada além da dedicatória e o Prefácio Interessantíssimo somam-se 22 poemas, e sinaliza sua predileção pela cidade imagética.

Mário de Andrade torna-se conhecido em todo o Brasil, pessoas escreviam cartas, poemas e sempre recebiam a resposta. Logo após a Semana de Arte Moderna, proclama-se o modernismo no Brasil, cuja data do evento também tinha sido estrategicamente escolhida pela comemoração do centenário da Independência. A repercussão na imprensa brasileira é contundente, pairava entre críticas ofensivas e elogios em toda a mídia. Em Sáo Paulo principalmente os jornais Correio Paulistano e O Estado de S. Paulo, corroboram para a publicaçáo sobre o assunto mais atualizado do momento.

A obra Pauliceia desvairada veio a se constituir no marco inicial da produçáo poética do modernismo brasileiro que alcança e influência outros escritores e artistas da época no Brasil. A cidade moderna inspira o poeta. A temática da modernidade, a preocupação cosmopolita, as transformaçóes urbanas, aguçam suas percepçóes para o deslumbramento e acontecimento do novo espírito, das novas imagens urbanas.

Mário Raul de Morais Andrade (1893-1945), também cresceu junto com a cidade e a garoa, que caía nos fins das tardes de outono e inverno e que provocava um intenso frenesi nas ruas em décadas de vinte e trinta. $\mathrm{O}$ friozinho provocava as pessoas para os cafés, sempre cheios, era possível sentir as fragrâncias vindas de Paris misturadas a elegantes fumaças desenhadas pelos charutos, cigarros e cachimbos, que se espalhavam pelo ar, Mário ali também estava imbuído pelo L'Esprit Nouveau da época.

Também conhecido como o poeta que canta a cidade de São Paulo com o ofício imagético de poetar pelas ruas da cidade cinzenta, garoenta e paradoxal, cujas paisagens urbanas sáo contrastantes, arlequinais, diversas e que dizem respeito a uma Pauliceia desvairada, repleta de movimentos apressados, de muitas faces, sons e fumaças.

Assim como ele, uma cidade arlequinal, cheia de máscaras, dissimulaçóes, encantos, desencantos e representaçôes. Mário de Andrade passa parte da infância e adolescência 
na área central da cidade, na rua Aurora, e no Largo Paissandu onde passou a mocidade e por fim na rua Lopes Chaves, no bairro da Barra Funda zona oeste da capital paulista, até sua morte. O crítico Lafetá corrobora com essa imagem de São Paulo na literatura e aponta.

Em primeiro lugar, trata-se de perguntar como seria possível representar poeticamente uma cidade táo complexa, que mistura tantos traços arcaicos a traços ultramodernos e traços cosmopolitas a outros tipicamente brasileiros. Essa é uma espécie de dúvida que assalta todo mundo, sendo que boa parte dos visitantes que aqui vêm pela primeira vez, fica horrorizada com a cidade. (...)

Não sou paulistano, sou mineiro do interior e sofri este choque há 25 anos atrás, quando Sáo Paulo era bem mais amena do que hoje. Foi justamente nessa época que tomei conhecimento, pela primeira vez, da poesia de Mário de Andrade. Foi uma surpresa tão grande quanto a cidade. Conhecer São Paulo e a poesia de Mário de Andrade, ao mesmo tempo, foi uma experiência fascinante. (LAFETÁ, 1997 , p. 85)

O olhar de Mário de Andrade por São Paulo em Paulicéia desvairada, ou mesmo a sua representação lírica, vai ser a imagem do "trovador arlequinal, do poeta sentimental e zombeteiro que encarna o espírito da modernidade e de suas contradiçóes” (LAFETÁ, 1986, p.15).

Lafetá coloca que na obra de Paulicéia desvairada, logo no Prefácio Interessantíssimo, o poeta apresenta aspectos peculiares da literatura moderna "a visão de São Paulo por Mário de Andrade dos anos 20 nos é através de um entrecruzamento de sensaçóes, uma espécie de sinestesia romântica” (LAFETÁ, 1997, p. 88). Ainda segundo o autor o poema Inspiração é uma "evocação à musa, que é justamente a cidade de São Paulo". A cidade de Sáo Paulo das primeiras décadas que antecederam os anos vinte, sob o olhar de Mário de Andrade é: "A cidade moderna é o labirinto arquitetônico que o homem criou à imagem de sua alma” (LAFETÁ, 1986, p. 20).

Esse debate sobre a cidade e a personalidade de Mário é amplamente discutido na literatura. Lafetá ainda coloca que Mário persegue essa identidade nos poemas da Pauliceia, ser um sujeito lírico capaz de fazer a cidade brilhar no interior do "eu", e este refletir-se na garoa ou no sol da cidade. (LAFETÁ, 1986, p. 19). Enfim, o crítico, costura a relação do poeta, da cidade e sua obra Pauliceia Desvairada diante do surgimento do Modernismo.

A Paulicéia Desvairada éo movimento, feito pela primeira vez pelo Modernismo, no sentido de atualizar "a inteligência artística brasileira". E atualizar significa acertar o relógio de nossa história pela hora dos grandes centros produtores de cultura: importa-se a estética da vanguarda para também produzí-la aqui, e ao tupi permanece tocador de alaúde. Aí está a fonte de outra discrepância que atinge a forma dos poemas: algo do artificialismo da Paulicéia vem com certeza do fato de que a poética importada não correspondia à realidade local, muito mais limitada e provinciana do que Paris, seu ponto de origem. (LAFETÁ, 1986, p.20) 
Em 1920 a cidade de São Paulo que o inspira parece ser tão ruim, contraditória, artificial e falsa, quanto as poesias de Pauliceia. "As reticências, as grandes exclamaçóes, os neologismos preciosos (retórica e amaneiramento que o poeta nunca abandonou de todo) são os responsáveis por uma sensação penosa de artificialismo e falsidade”. (LAFETÁ, 1986, p.17)

Mário procura sua identidade com a cidade carregado de cabotinismo e conflitos pessoais. As várias máscaras do poeta são dissonantes e imbuídas de sentimentos caóticos, assim como a cidade. Mesmo em busca do seu próprio eu. É de seu caminhar pelas ruas da cidade que nascem os poemas. Seus caminhos eram a Barra Funda, onde morou desde 1921, a Vila Mariana, Avenida Paulista, Higienópolis, Brás, Cambuci, enfim região central da cidade. Seu olhar perdido nas multidóes, a fumaça das primeiras fábricas e automóveis, o movimento, a agitação da cidade que imprimirá em Pauliceia.

$\mathrm{Na}$ análise do crítico sobre o poema Paisagem no 1 , ele aponta a imagem da cidade para o poeta.

\section{PAISAGEM No1}

Minha Londres das neblinas finas...

Pleno verão. Os dez mil milhóes de rosas paulistanas.

Há neves de perfumes no ar.

Faz frio, muito frio

E a ironia das pernas das costureirinhas

Parecidas com bailarinas...

O vento é como uma navalha

Nas mãos dum espanhol. Arlequinal...

Há duas horas queimou sol.

Daqui a duas horas queima sol.

(...)

Enquanto o cinzento das ruas arrepiadas

dialoga um lamento com o vento...

Meu coraçấo sente-se muito alegre!

Este friozinho arrebitado

Dá uma vontade de sorrir!

E sigo. E vou sentindo,

Á inquieta alacridade da invernia,

Como um gosto de lágrimas na boca... (ANDRADE, 2009, p. 40)

"Pleno verão. Os dez milhôes de rosas paulistanas. /Há neve de perfumes no ar" E é que "artificial" e "falsa" são adjetivos que não se aplicam apenas à dicção do livro, mas também à imagem da cidade que ele apresenta. Ou dizendo melhor: não é só a poesia que parece ruim, mas ainda sua matéria nutridora, a cidade a inspira. (LAFETÁ, 1986, p.17) 
Lafetá (1986, p.17) escreve sobre o mau gosto da Pauliceia desvairada. Faz uma analogia com a música Sampa do compositor Caetano Veloso, que expressa seus sentimentos sobre a cidade quando aqui chega, seu estranhamento remete a uma cidade fria, desumana, fragmentada. E canta a cidade: "É que Narciso acha feio o que não é espelho / E à mente apavora o que ainda não é mesmo velho". São Paulo é uma cidade grande, cosmopolita, perversa e "Para quem vem de qualquer outro sonho feliz de cidade, a metrópole é o avesso do avesso do avesso".

Esta cidade que não reflete o rosto de seus habitantes é - disse Oswaldo - a "cidade de Mário de Andrade". Sua duvidosa poesia é áspera, tortuosa, fragmentada; difícil mesmo encontrá-la, exprimi-la ou entendê-la. Mas é isso que Mário tenta fazer, e quanto os olhos e a mente se acostumam ao novo (os olhos e a mente do poeta assim como os do leitor), é possível ver surgirem os "deuses da chuva", num poema raro e realizado como este: (LAFETÁ, 1986, p.18).

Em Paisagem no 3, o raro poema não apenas escrito mais realizado, conforme o autor, consegue a felicidade de se expressar harmoniosamente e provocar a sensação de beleza, em vez de sofrimento, ferida e discrepância como nos demais poemas. E ainda, o poeta consegue fazer a cidade brilhar no seu interior, momento de raro desprendimento e sutileza. (LAFETÁ, 1986, pp.18-19)

\section{PAISAGEM No 3}

Chove?

Sorri uma garoa cor de cinza,

Muito triste, como um tristemente longo...

A casa Kosmos não tem impermeáveis em liquidação...

Mas neste largo do Arouche

Posso abrir meu guarda-chuva paradoxal

Este lírico plátano de rendas mar...

Ali em frente... - Mário, põe a máscara!

- Tens razão, minha Loucura, tens razão.

O rei de tule jogou a taça ao mar...

Os homens passam encharcados...

Os reflexos dos vultos curtos

mancham o petit-pavé...

As rosas da Normal

esvoaçam entre os dedos da garoa... (...)

De repente

Um raio de Sol arisco

risca o chuvisco ao meio. (ANDRADE, 2009, p. 57). 
Durante a estada de Blaise Cendrars ao Brasil em 1924, o grupo modernista redescobre o Brasil ao acompanhá-lo em sua excursão nacional. Dona Olívia Penteado formou o grupo representado por Mário de Andrade, Oswald de Andrade, Tarsila do Amaral, René Thiollier e Godofredo da Silva Telles. Com as malas prontas ansiosos partem de São Paulo para assistir o Carnaval no Rio de Janeiro. "No Rio, Blaise frequentaria por sua conta o morro da Favela, ficaria amigo de Donga, Manuel Bandeira e da rapaziada do Cinema Poeira, "um clube de negros seletos" (SEVCENKO, 2014, p. 295).

Depois prosseguiram viagem as cidades históricas de Minas Gerais. O deslumbramento pela obra de Aleijadinho seria magnífico. Sob a orientação e influência do poeta, Tarsila que também participou da viagem reproduz em suas telas tudo que via pelos caminhos do Brasil, trata-se de sua fase Pau-Brasil, segundo Aracy Amaral (2006, p.45). As telas nessa fase expressam as raízes históricas, regionais, étnicas e culturais, as cores das pinturas são bastante vibrantes e reveladora de um país tropical. A exemplo uma das telas dessa fase Pau-Brasil de Tarsila. Dessa fase originará o Movimento Antropofágico.

\section{Figura 3 - Morro da Favela, 1924 - Tarsila do Amaral - Óleo sobre tela, 64,5x76 cm, (P074), Coleção Hecilda e Sergio Fadel, RJ, RJ}

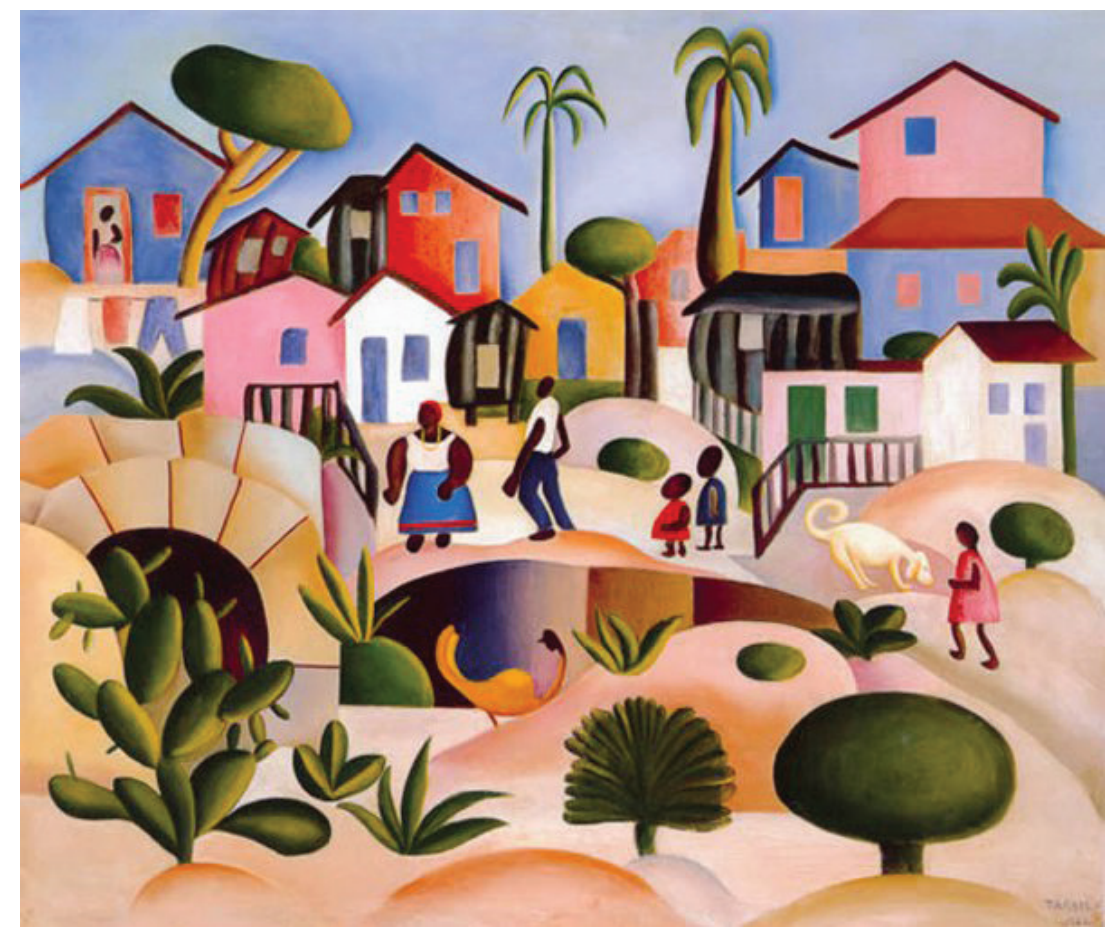

http://tarsiladoamaral.com.br/obras/pau-brasil-1924-1928/ acesso 16 Jan. 2017

Em Clã do jabuti Mário de Andrade em sua fase Pau-Brasil escreve sobre o carnaval carioca. Visitado por ele e os modernistas em companhia de Blaise Cendrars. É notório seu entusiasmo e deslumbramento pela cidade do Rio de Janeiro e pelo carnaval, expressado em seus versos. 


\section{CARNAVAL CARIOCA (1923)}

Minha frieza de paulista,

a Manuel Bandeira

A fornalha estrala em mascarados cheiros silvos

Bulhas de cor bruta aos trambolhóes,

Cetins sedas cassas fundidas no riso febril...

Brasil!

Rio de Janeiro!

Queimadas de verão!

E ao longe, do tição do Corcovado a fumarada das nuvens pelo céu.

Carnaval...

Minha frieza de paulista,

Policiamentos interiores,

Temores de exceção...(...)

Carroças na rua transatlânticos no mar...

É a cantiga-de-berço.

E o poeta dorme.

O poeta dorme sem necessidade de sonhar. (ANDRADE, 2009, p.171 e 185)

\section{CONSIDERAÇÓES FINAIS}

A respeito das percepçóes sobre a repercussão da Semana de Arte Moderna no Brasil, o Professor Wilson Martins coloca em seus escritos literários, que o esgotamento estético dos passadistas era inegável e irremediável e que a partir da publicação de Pauliceia desvairada o tom da literatura torna-se revolucionaria e criadora de uma nova estética nacional. A Semana de Arte Moderna culminou nesse processo criativo.

.... Semana de Arte Moderna foi o coroamento de todo um processo intelectual. O Modernismo tomou, com ela consciência de si mesmo, a vanguarda representando nesse momento, como sempre acontece, o grupo que primeiro compreendeu, embora obscura e contraditoriamente, a verdadeira natureza dos anseios e manifestaçóes esparsas que se vinham repetindo, cada vez com maior insistência, desde os primeiros anos do século. Quando se realiza a Semana de Arte Moderna, escrevia eu no Panorama das literaturas das Américas, o Modernismo já está maduro, se não no grande público, pelo menos entre os intelectuais que compunham, naquele momento, a parte mais viva e criadora da inteligência brasileira. A Semana introduzia "oficialmente" um novo estado de espírito e foi, com toda a certeza, a mais profunda de todas as nossas revoluçóes literárias. (MARTINS, 2002, p.21). 
A cidade de Sáo Paulo que serviu de palco para o desabrochar da estética Modernista e os acontecimentos da Semana de 22, permanece na demanda por tempos modernos. Mesmo em meio ao emaranhado das relaçóes sociais, das contradições, dos desencontros e dos dessabores que a sociedade moderna condiciona. Fica aqui expressada a fala do poeta.

"a estética do Modernismo ficou indefinível"... Pois essa é a melhor razão de ser do Modernismo! Ele não era uma estética, nem na Europa nem aqui. Era um estado de espírito revoltado e revolucionário que, si a nós nos atualizou, sistematizando como constância da Inteligência nacional o direito antiacadêmico da pesquisa estética e preparou o estado revolucionário das outras manifestaçôes sociais do país, também fez isto mesmo no resto do mundo, profetizando estas guerras de que uma civilização nova nascerá. (ANDRADE, 1974, p. 251)

Na década de 1920, a cidade cresce e está cheia de vida e burburinhos. Segundo Petrone (1956, p.132), a partir de 1916 a Light passa a fornecer luz elétrica, as ruas principais do centro estáo pavimentadas, há serviços de água, esgotos e transporte, que contribuem com o planejamento da cidade. Anteriormente, a Pauliceia abrigava um ar "tristonho e provinciano" (PETRONE, 1956, p.132). Mas seu coração pulsava por encontros, luzes e mais luzes. No início do século XX, a maioria das ruas paulistanas era iluminada a gás.

No entanto, a partir de 1922 ocorre a expansão da iluminação elétrica, em várias partes da cidade, mesmo em bairros mais distantes da área central, como Água Branca, Lapa, Ipiranga e Penha.

$\mathrm{Na}$ região central, preponderavam as obras urbanísticas. Em 1915, iluminação do Trianon (Miradouro) da Avenida Paulista; em 1916, todo o Triângulo, a esplanada do Teatro Municipal e os relógios públicos. A partir de 1918, da Avenida Paulista até ao Vale do Anhangabaú, a Bela Vista e o Largo da Concórdia (Brás). Os fios elétricos viajam em 1922 até o Jardim América, Santana e Ipiranga.

Petrone (1956, p.132) diz que "em 1907, existiam na cidade 4.558 combustores de gás; em 1915, esse número elevou-se para 9.396, o que correspondia a dez vezes o de focos elétricos; e, em 1922, atingiu 10.031". Nessa época existia o acendedor de lampióes que, de maneira pontual, percorria as ruas da cidade para lhe oferecer um pouco de brilho e alegria. A seguir, um desenho ilustrado pela modernista Tarsila do Amaral no livro Obras completas, poesias reunidas de Oswald de Andrade. 
Figura 4 - Postes da Light, Tarsila do Amaral

\section{Postes da Light}

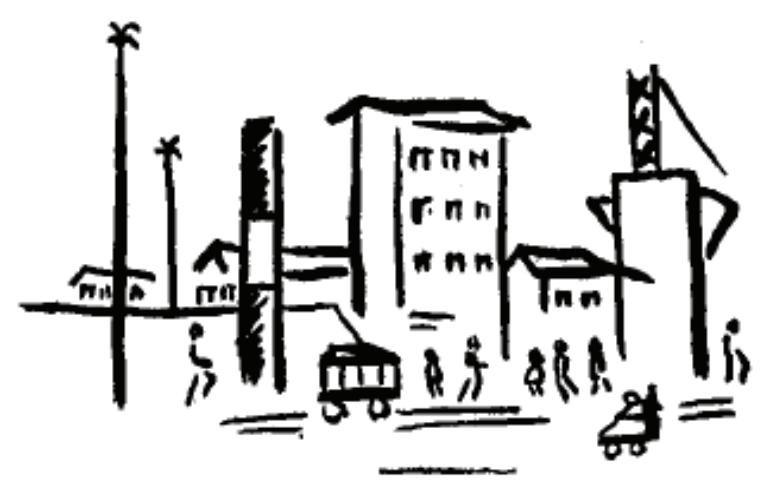

Fonte: ANDRADE, Oswald. Obras completas - poesias reunidas. 1971, p.119.

"Seis horas lá em S. Bento"

Seis horas lá em S. Bento.

Os lampióes fecham os olhos de repente

À voz de comando do sino.

A madrugada imensamente escura

Abafa as arquiteturas da praça.

E a estátua de Verdi Também, graças a Deus!

[...]

Faz frio de geada esta manhâ...

A gente se encosta nos outros, pedindo

Uma esmolinha de calor.

E o bonde abala sapateando nos trilhos

Em busca das casernas sinistras cor-de-chumbo.

(ANDRADE, 2009, p. 116)

A estruturação da grande Sáo Paulo, escrito por Juergen R. Langenbuch, a evolução pré-metropolitana dos arredores paulistanos ocorre nos anos de 1875-1915. Com base na historiografia, em documentos e plantas da cidade, nos estudos de Caio Prado, de A. de Azevedo, Pasquale Petrone, Odilon Nogueira de Matos e Pierre Monbeig, entre outros, chega-se a uma caracterização interessante de São Paulo e arredores: 
O antigo cinturão de chácaras foi anexado à cidade através de bairros e loteamentos... o antigo cinturão caipira foi valorizado... instalaramse várias atividades econômicas: extrativismo mineral e vegetal, indústria de beneficiamento e vitivinicultura. O crescimento da cidade expulsou hospitais carentes de isolamento... a ferrovia funcionou como instrumento da reorganização... conferiram as faixas por ela servidas vocação suburbana. Os povoados-estação seriam embriōes de importantes núcleos suburbanos... (LANGENBUCH, 1968, p. 140)

Para o autor Juergen Langenbuch, o período de 1915-1940 é compreendido como o do início da metropolização de São Paulo. A estrada de ferro está presente em novas artérias da cidade e mais uma vez surge a figura do bonde. A cidade se expande, são esses novos caminhos que trazem a industrialização. Surgem novos povoados, que se transformam a princípio em pequenas vilas de operários e mais tarde se emancipam e formam novas cidades, como por exemplo: São Bernardo do Campo, Santo André, Osasco, entre outras.

O bonde continua arrojado. Passou a servir um bairro de origem anterior a 1915, a Casa Verde... foi estendido a vários bairros, Vila Maria, Heliópolis, Parque da Saúde, Jardim Paulista, Jardim Europa, Jardim Paulistano, Alto da Lapa... A estrada de ferro náo se limitou a orientar a suburbanização residencial, mas continuou a fazê-lo com relação à suburbanização industrial. (LANGENBUCH, 1968, p.140)

Figura 5 - Viaduto do Chá visto a partir do prédio localizado na esquina da Rua Líbero Badaró, em direção à Rua Barão de Itapetininga (1918) - Autor (Aurélio Becherini).

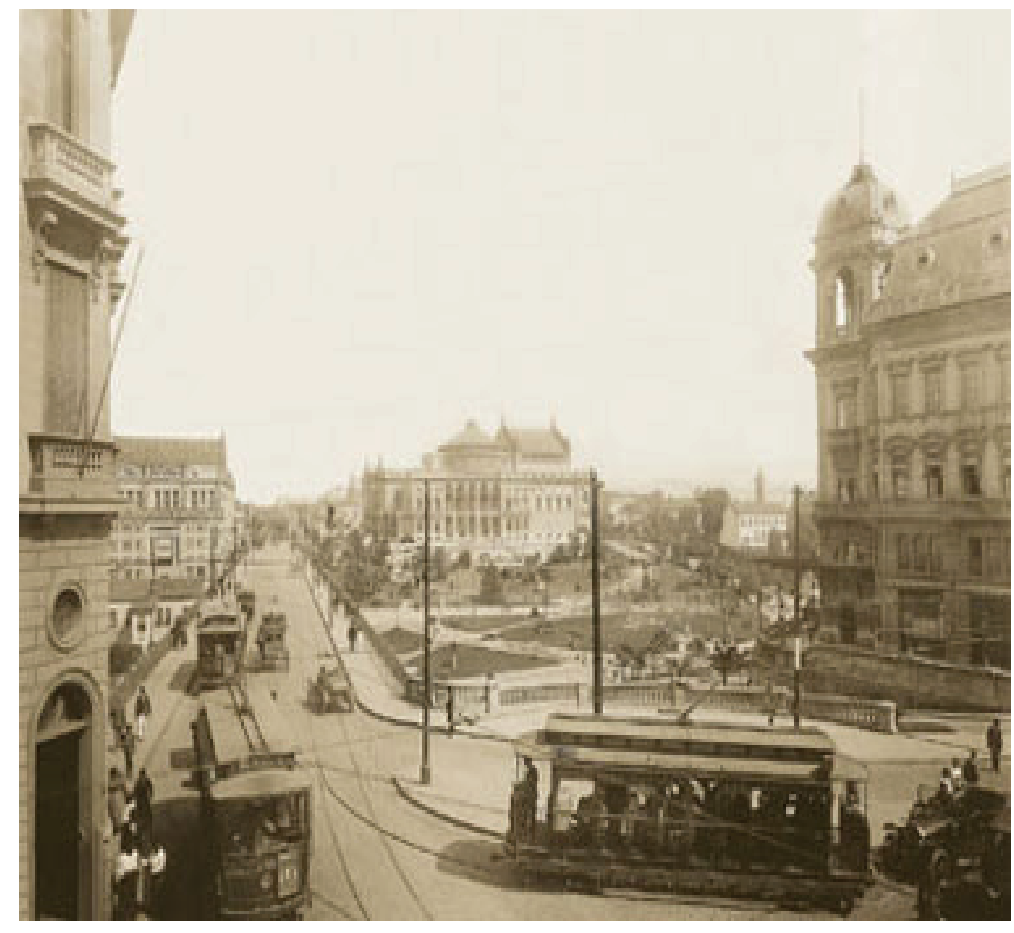

Fonte: São Paulo de Piratininga: de pouso de tropas a metrópole. São Paulo: Terceiro Nome. CD-ROM 


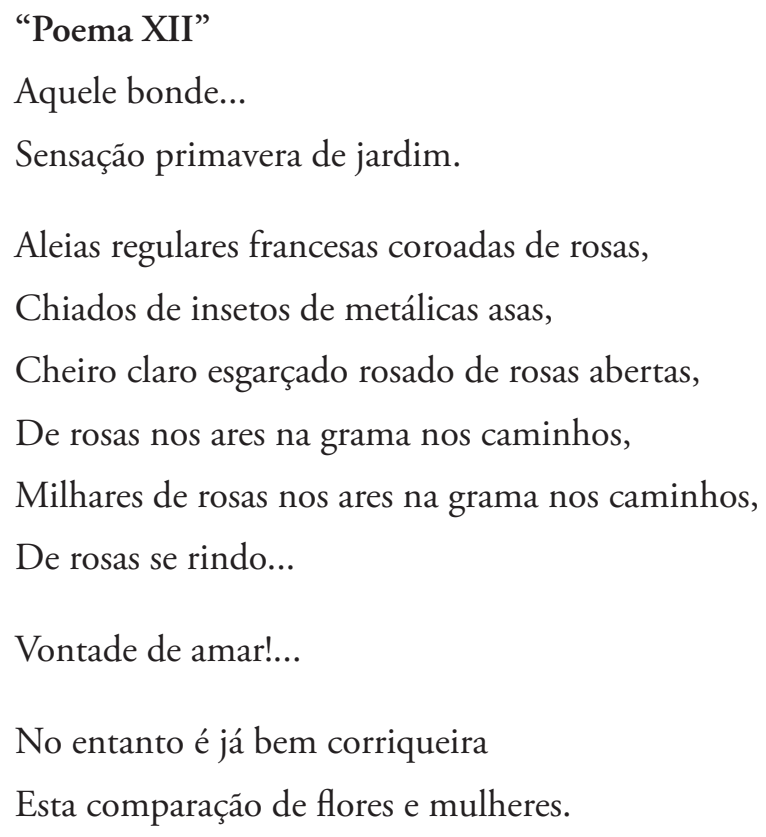

(ANDRADE, 1987, p.115)

Evocar as imagens do passado traz à luz o vislumbrar de um tempo distante, que a imaginação não alcança; assim, é possível olhar a Pauliceia através dos sentimentos imbuídos nos poemas do poeta modernista e revisitar a cidade de São Paulo nas primeiras décadas do século XX. É possível identificar o crescimento da área central e o uso do espaço pela população, seja pelas quantidades de edificaçóes, o comércio, o trabalho e o cotidiano do paulistano, ou mesmo daqueles que chegaram de longe e encontraram uma cidade pitoresca, multifacetada, com variadas funçôes e subterfúgios. A fotografia a seguir, fragmenta características da paisagem urbana da cidade de São Paulo na década de 1920.

Assim, o emaranhado do tempo e das relações sociais são ingredientes presentes na modernidade da paisagem urbana da cidade, que se estende as artérias artísticas, literárias e chegam como um despoeiramento da inteligência nacional. Mário de Andrade, celebra o modernismo em todas as suas obras e ainda, exercita o papel de protagonista do desvairismo moderno, que vai perpetuar até os anos de 1945, data de sua morte e do surgimento da Geração de novos escritores brasileiros. 
Figura 6 - Jardins do Parque do Anhangabaú (1925)

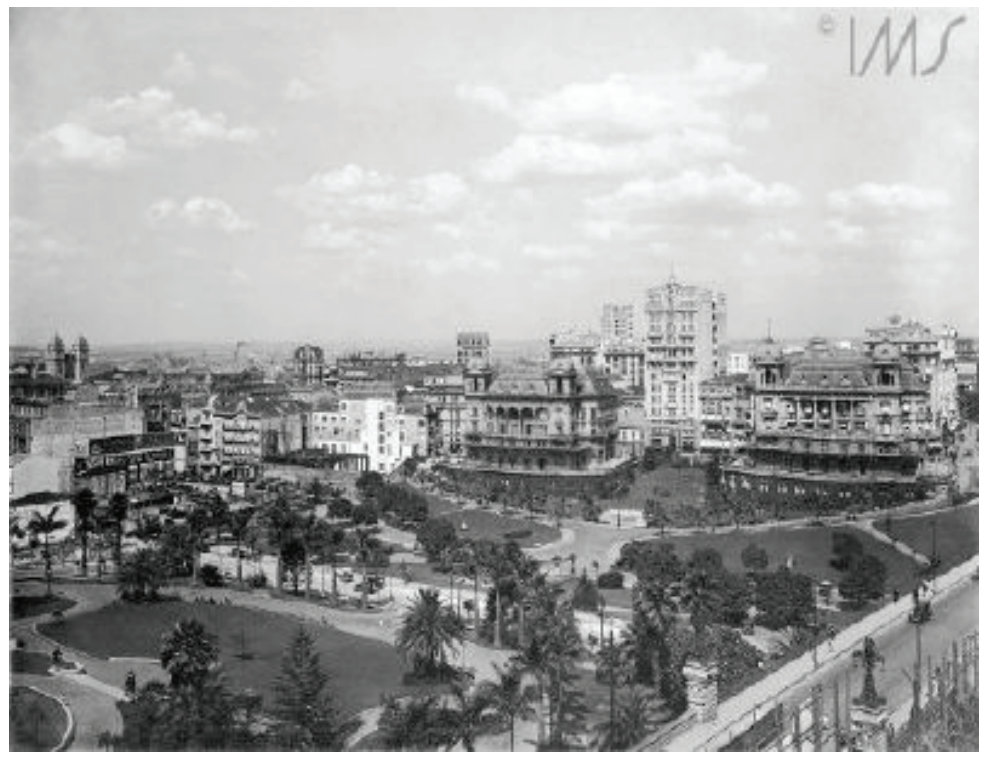

Coleção Guilherme Gaensly. Fonte: Instituto Moreira Salles http://fotografia.ims.com.br/. Acesso em: 14 jan. 2017. 


\section{REFERÊNCIAS BIBLIOGRÁFICAS}

ANDRADE, Mário de. Aspectos da literatura brasileira. 5. ed. São Paulo: Martins Editora, 1974.

Poesias Completas. Telê Ancona Lopes (Org.) Tatiana Maria Longo dos Santos (Org.) Rio de Janeiro: Vida Melhor, 2009.

AMARAL, Aracy. O Modernismo brasileiro e o contexto cultural dos anos vinte. REVISTA USP, Sáo Paulo, n. 94, pp. 9-18, Junho/Julho/Agosto/ 2012.

ESCOREL, Lilian. L’Esprit Nouveau nas estantes de Mário de Andrade. São Paulo: Humanitas /FAPESP, 2011.

FONSECA, Aleilton Santana. A Poesia da Cidade Imagens urbanas em Mário de Andrade. São Paulo, 1997. 311f. Tese (Doutorado em Letras Clássicas e Vernáculas) - Faculdade de Filosofia, Letras e Ciências Humanas da Universidade de São Paulo.

LAFETÁ, João Luiz M. 1930: A Figuração da Intimidade. 1. ed. São Paulo: Livraria Martins Fontes Editora Ltda., 1986.

1930: A Crítica e o Modernismo. São Paulo: Livraria Duas Cidades Ltda., 1974.

. 1930: A Dimensão da Noite. 1. ed. São Paulo: Editora 34 Ltda., 2004.

A representação da cidade de Sáo Paulo em dois momentos da poesia de Mário de Andrade. In: SILVA, Lúcia Neíza Pereira da. Mário Universal Paulista: Algumas Polaridades. São Paulo: s. n., 1997, pp. 85-93.

LANGENBUCH, Juergen Richard: A estruturação da Grande São Paulo. São Paulo, 1968. Tese de Doutorado apresentada a Faculdade de Filosofia, Ciências e Letras de Rio Claro da Universidade de Campinas.

MAJOR, José Emílio Neto. A Lira Paulistana de Mário de Andrade: a insuficiência fatal do Outro. São Paulo, 2006.275f. Tese (Doutorado em Teoria Literária e Literatura Comparada) - Departamento de Teoria Literária e Literatura Comparada da Faculdade de Filosofia, Letras e Ciências Humanas da Universidade de São Paulo.

MARTINS, Wilson. A Ideia Modernista. Rio de Janeiro: Topbooks Editora e Distribuidora de Livros Ltda., 2002.

PETRONE, Pasquale. São Paulo no século XX - In. A cidade de São Paulo: Estudos de geografia urbana. São Paulo: Companhia Editora Nacional, 1958, pp.101-160. v.2.

SEVCENKO, Nicolau. O Orfeu Extático na Metrópole. 5. ed. São Paulo: Companhia das Letras, 1992.

Recebido em junho de 2017. Aprovado em dezembro de 2017. 